\title{
Relations between Historical Researchers and Custodians of Source Materials
}

This article reports a survey dealing with various problems encountered by graduate students in history while doing dissertation research with original sources. Among them are the willingness of professors to work with librarians in building collections, accommodations for visiting researchers, use of microforms, intramural friction between librarians and history professors, and admission policies of private libraries. The survey found that researchers generally enjoy good relations with librarians. By identifying areas where friction remains and where relations can be improved, the article aims at constructive criticism.

I $N$ HIS TRAVELS connected with this survey, the author visited 112 institutions, seventy of which grant graduate degrees in American history. The remaining forty-two are libraries, historical societies, archives, museums, federal records centers, manuscript collections, and other such repositories. It rapidly became clear from the survey's 557 interviews with professors directing research, graduate students, and custodians of primary sources that the effectiveness of research depends in no small measure on relationships between the researcher and the repository. These relationships have many dimensions.

Generally, the relationships between historical researchers and the librarians

Dr. Rundell is Professor of History in the University of Oklahoma. He was Director of the Survey here reported during its twoyear existence, September 1965 through August 1967. It was sponsored by the National Historical Publications Commission and funded by a grant from the Ford Foundation. and archivists charged with the custody of research materials are excellent. Any researcher naturally encounters difficulties and frustrations, and a historian would be naive to expect this phase of his work to be without hindrance. Perhaps the reason scholars express annoyance with obstacles to research is that they have usually chosen and pursued their profession because of deep commitments that transform their labor into intellectual pleasure and excitement. When this activity is beset with problems, scholars realize-as do their laboring brothers daily-that work is not play. If scholars were not following or preparing for an idealized vocation, they probably would take ordinary aggravations with less fret. Since scholarly research does intersect the workaday world, historians should be prepared for their relations with curators and clerical assistants to be something less than perfect. The encouraging fact is that these relations are strikingly cordial. This discussion of existing problems attempts to 
identify areas where custodians and historians can work together to facilitate scholarly research.

An indication of the close cooperation between historians and university library staffs is that the latter frequently comment that professors and students from the history department are the library's most active users. The reference department of the Rutgers University library "sometimes feels that it's working for the department of history" since it has more requests from that department than any other. "There are more historians in the library than scholars from any other discipline." 1 At Louisiana State University the library's relations with the history department are "the best we have on campus." The social science librarian at Florida State University thinks excellent relations with historians result from the "library-minded people in the history department." He comments further on a condition the survey frequently encountered: the history department's spending "its share of the budget and more." ${ }^{3}$ Library staffs at the Universities of Minnesota and Nebraska and at Washington University say that historians are among their heaviest users. At the University of Utah and Emory University, only the English departments are as interested as historians in building the library collections. ${ }^{4}$

Both university libraries and non-academic repositories often insure good working relations by having historians on their governing boards and as directors. At Washington University the chairman of the faculty library council is a historian; ${ }^{5}$ and in Philadelphia, Roy Nichols and Thomas C. Cochran are on the

\footnotetext{
1 Interview with H. Gilbert Kelley, reference librarian, September 28, 1966.

${ }^{2}$ Interview with T. N. McMullan, director, March 16, 1966.

3 Interview with Reno W. Bupp, July 29, 1966.

4 Interviews with Richard W. Boss, assistant director libraries, University of Utah, June 21, 1966; Guy R. Lyle, director of libraries, Emory University, December 8, 1965.

Interview with Andrew J. Eaton, librarian, Washington University, April 19, 1966.
}

board of the Historical Society of Pennsylvania, and Anthony N. B. Garvan is on the board of the Library Company of Philadelphia. ${ }^{6}$ In some institutions, such as the Universities of Oklahoma and North Carolina, historians hold joint appointments in the library. At the former, Arrell M. Gibson and Duane H. D. Roller are both professors and curators of the Western History and DeGolyer Collections, respectively. ${ }^{7}$ At the latter, James W. Patton was professor and director of the Southern Historical Collection until his retirement in 1967. His successor, J. Isaac Copeland, is also a $\mathrm{PhD}$ in history. Similarly, at the University of Wyoming, Gene M. Gressley teaches and is director of the Western History Research Center. Some libraries cement their relations with historians by having PhD's in history as directors, such as Stuart Forth of the University of Kentucky, Lawrence W. Towner of the Newberry Library, and Dorman H. Winfrey of the Texas state library. Boston University has assured "intimate" relations with the Boston Athenaeum by owning two shares of its stock. This provides professors and graduate students free access to the Athenaeum's library. ${ }^{8}$

Historians' infiltration of the directorships and governing boards of repositories may establish the principle of close liaison, but graduate students embarking on a research trip need something more practical. Fortunately, they frequently find that their professors have prepared the way for them. This preparation has not been individual and specific, but has resulted from professors having used repositories for years and having established amicable working relations with the curators. Their students, in turn, profit from the cumulate good will. Doctoral candidates at several uni-

\footnotetext{
- Interview with Cochran, August 25, 1966.

7 Interview with Arthur M. McAnally, director, University of Oklahoma Library, March 9, 1966.

Interview with Robert E. Moody, October 28,
} 
versities said that their major professors' reputations paved the way and opened doors for them wherever they went for research.

Since many graduate students do little research at their home institutions, it is fortunate that they ordinarily enjoy excellent relations with curators, irrespective of whether or not their professors' reputations have preceded them. This avoidance of university libraries may result from generally inadequate holdings or the dissertation topic being unrelated to the library's collections. It is to be expected that students may not choose topics related to local resources, but when repositories formulate their collecting policy to support research in certain areas, they are naturally disappointed at the neglect of these areas. For instance, the Arizona Pioneers' Historical Society (the state historical society), located in Tucson near the University of Arizona, reports: "Our trouble is that so few of both the faculty and graduate students are pursuing Western American (or even American) studies." 9

Part of the preparation professors give students prior to research trips is a discussion of what they should expect and how they should behave at research institutions. ${ }^{10}$ Philip P. Mason finds it particularly helpful to acquaint students with the finding aids from the repository to be visited. ${ }^{11} \mathrm{~A}$ doctoral candidate at the University of California at Berkeley regretted that his professors had said nothing about the protocol in visiting other libraries. "We were not told, for instance, that we should write ahead to tell the library of our project and what we would like to see."

Many professors have found that letters of introduction enhance students' relations with research institutions, and

\footnotetext{
${ }^{9}$ Questionnaire returned by Andrew Wallace.

10 Interviews with Don Higginbotham, Louisiana State University, March 16, 1966; Hugh F. Rankin, Tulane University, March 18, 1966.

${ }^{11}$ Interview at Atlanta, Georgia, October 5, 1966.
}

they will send letters either before the visit $^{12}$ or with the student. ${ }^{13}$ The department at Yale University tries to introduce graduate students formally each time they visit another research institution. ${ }^{14}$ Because New York City abounds in all sorts and conditions of students, Columbia University history professors feel that they need to be more formal than they might otherwise be when sending students to other repositories. If a student goes elsewhere for research, his professor gives him a letter of introduction, stating the nature of his research interest. ${ }^{15}$ Eric Foner, a Columbia graduate student, has found that such a letter eases any problems that may arise ${ }^{16}$ and doctoral candidates at the Universities of Illinois and California at Santa Barbara have reported that letters from their professors have had similar results. ${ }^{17}$ When graduate students from the University of Kansas travel overseas for research, the Chancellor gives them a letter of identification, and they have had no problems. ${ }^{18}$

A sure sign of good relations between repositories and researchers is the willingness of repositories to make special accommodations for its users. Since special collections often are closed after five o'clock and since traveling researchers need to use their time as effectively as possible, it is a great help when the repository will permit the researcher to come in after hours or transfer the material to another unit in the building that keeps later hours. Frequently institutions initiate these special arrangements to aid their own researchers, and visitors subsequently benefit.

Some libraries make special lending

\footnotetext{
12 Interview with Merle Curti, University of Wisconsin, May 24, 1966.

${ }^{13}$ Interview with Stephen E. Ambrose, Johns Hopkins University, November 10, 1965.

14 Interview with Howard R. Lamar, July 12, 1966.

15 Interview with Robert D. Cross, July 18, 1966.

16 Interview, July 18, 1966.

17 Interviews with Edmund J. Danzinger, Jr., May 27, 1966; George E. Frakes, January 17, 1966.

${ }^{18}$ Interview with W. Stitt Robinson, April 23, 1966.
} 
arrangements for scholars needing to use materials for prolonged periods. The University of Texas library has made extended loans of books to graduate students from Texas Christian University, ${ }^{19}$ and the Rayburn library in Bonham, Texas, once let a graduate student from the University of Cincinnati take material back to Cincinnati. This student was virtually the only researcher at the library in the summer of $1965 . .^{20}$ Any time that a scholar is the only researcher in a library, he can usually count on the full attention and cooperation of the staff. This was Gabriel Kolko's experience when he visited the Eisenhower library in July $1966 .{ }^{21}$ If regulations permit, staffs will sometimes let mature researchers into the stacks and thereby save time for all. The American Antiquarian Society did this for David L. Ammerman when he was working on his dissertation, "The First Continental Congress and the Coming of the American Revolution." He says he "could not have asked for better treatment."22

Another indication of an institution's consideration of its researchers' needs is its provision for using microforms and for photocopying. Doctoral candidates at the Universities of Utah, California at Berkeley, and Notre Dame have commented on the great assistance their libraries render with good microform collections and reading facilities. ${ }^{23} \mathrm{~A}$ University of Illinois student praised his library for scattering Docustat machines throughout the building. The charge of ten cents per page is well worth the typing time saved. ${ }^{24}$ Low photocopying

\footnotetext{
19 Interview with Ben Procter, Texas Christian University, March 4, 1966.

20 Interview with Thomas N. Bonner, University of Cincinnati, April 27, 1966.

${ }^{21}$ Interview at University of Pennsylvania, August $25,1966$.

${ }^{22}$ Interview at Florida State University, July 29, 1966.

${ }^{23}$ Interviews with William Dirk Raat, June 21, 1966; Lisle A. Rose, January 12, 1966; Paul A. O'Rourke, September 23, 1966.

24 Interview with Edmund J. Danziger, Jr., May 27, 1966.
}

fees are in part responsible for the cordial relations the Massachusetts Historical Society has with its researchers, according to Stephen T. Riley, the director. ${ }^{25}$ The American Jewish Archives claims-and no doubt rightly so-that it does for a researcher what no other archives in the world will do: make from fifty to seventy-five Xerox copies free. ${ }^{26}$

The staffs of some repositories maintain close relations with prospective researchers by informing historians of holdings on which specific topics could be based. When Morris Rieger was chief of the Labor and Transportation Branch in the National Archives, he would write scholars about unused records related to their research interests. ${ }^{27}$ The Colorado State Historical Society and State Archives similarly inform professors at the Universities of Colorado and Denver of their resources and suggest lists of subjects these resources will support. ${ }^{28} \mathrm{Li}$ brary staffs at the University of Kentucky and Saint Louis University likewise notify their history departments of topics that can be developed from their original sources. ${ }^{29}$

Other institutions have taken specific steps to make their services consonant with researchers' needs. The Massachusetts Historical Society believes in making its manuscripts easy to use and therefore gives a scholar a sufficient number to keep him occupied for several hours. ${ }^{30}$ To improve communication

\footnotetext{
${ }^{25}$ Interview, October 25, 1965.

${ }^{26}$ Interview with Jacob R. Marcus, director, April $27,1966$.

${ }^{27}$ Interview, December 9, 1966.

${ }^{28}$ Interviews with Enid T. Thompson, librarian, June 15, 1966; Delores Renze, State Archivist, June 15,1966 .

${ }^{29}$ Interviews with Stuart Forth, director of libraries; Jacqueline Bull, manuscripts curator; Kate Irvine, reference librarian; Rebekah Harleston, government documents librarian, University of Kentucky library, September 19, 1966; James V. Jones, director of libraries; Rose Brady, government documents collection; Catherine E. Weidle, rare books librarian; Charles J. Ermatinger, Vatican film librarian; and Edward R. Vollmar, S.J., associate director of libraries, Saint Louis University library, April 18, 1966.

${ }^{30}$ Interview with Stephen T. Riley, director, October $25,1965$.
} 
with historians in Pennsylvania, the Pennsylvania Historical and Museum Commission and Pennsylvania Historical Association have sponsored an invitational conference to acquaint historians with their facilities and resources. ${ }^{31}$ In planning its new library, Northwestern University has made users' needs the basis for the design. Clarence L. Ver Steeg, chairman of the university committee on the new library, said: "We tried to determine how students use the library and to put the needs of students ahead of the needs of the books. ... We did not start with a building, but with its functions." 32

Many of the frustrations historians do experience in their research result from problems within their academic institutions. Some of these are attributable to shortcomings within the library, but others stem from imperfect communication between history professors and the library. In some instances this situation is not peculiar to the department of history, but applies to all academic divisions of a university. At one university the librarian thinks that library-faculty relations would be improved considerably if the library staff had faculty status. Without qualifying for membership in the academic senate and not being able to attend its meetings, the librarians are not routinely apprised of faculty plans that involve the library. Consequently, the faculty sometimes makes plans that depend upon the support of the library without so advising the library. Such situations no doubt prevail in numerous universities. One way of insuring closer liaison between teaching and library staffs, in addition to giving the latter faculty status, would be for the directors of libraries at research institutions to have ex officio membership on the graduate council.

The head of the reference department

\footnotetext{
${ }^{31}$ Questionnaire returned by Pennsylvania Historical and Museum Commission, Donald H. Kent.

${ }_{32}$ Interview, September 27, 1966.
}

at a major university library says that, although the library has generally good relations with the history department, better coordination between professors and librarians on assignments involving the library would improve these relations. Without consulting with the library, professors frequently make assignments involving much library staff participation. "Since a limited staff must serve the entire campus community, this sort of thing may put a strain on the relationship at times." The librarians have sometimes thought that they have to spend more time with students in certain history courses than do their professors. At another university, the library staff considers its relations with the history department among the best in the university. But these relations depend too much on the few professors using the library. "It's just that we don't know many of the history professors."

Unfortunately, in some instances intramural hostility impairs the aid graduate students receive from research collections. When the department of history at one institution decided to de-emphasize the programs developed around an important research collection, relations deteriorated. The collection, which has a degree of autonomy, retaliated by making graduate students from that department feel unwelcome.

Aside from the basic problem of communication between librarians and historians, libraries' physical accommodations greatly influence researchers' attitudes. Historians complain about libraries that do not provide adequately for typewriters or that will not allow the use of them, either in carrels or in conjunction with microform readers. Historians also comment pointedly on their libraries' crowded or non-existent carrels. In addition to having inadequate carrels, libraries deter research when they provide no place where materials can be locked up or left out undisturbed. Students waste a great deal of time hav- 
ing to tidy up each time they leave their work area. When libraries have limited physical facilities, they often cannot provide space for departmental studies or seminar rooms, as well as carrels. In addition some libraries serve as a social center, especially when the university has no student union.

Crowding in some libraries has resulted in preferential treatment for the most-used items, and research materials get pushed into spaces inaccessible to students, e.g., rather than being able to browse in government documents, students may have to call for them by number. Inadequate space has forced many repositories to store the less frequently used parts of their collections. When researchers need this material from storage, the results can be frustrating. The limited space in one university library has necessitated its storing an appreciable portion of its holdings, and it sometimes takes two weeks for a researcher to get material from storage. An important research collection must maintain some records in an annex twenty-two miles away. Because of this distance, the staff can service the records only once a week, which "inconveniences researchers and causes delay."

Any researcher using the manuscript collection of the University of California at Los Angeles must recognize that no manuscripts are available immediately. They are stored in a sub-basement vault and student help can provide only oncea-day paging service. Even if a request is submitted just before three o'clock when the paging begins, manuscripts would not likely be available before 4:30 P.M. Since the collection closes at five, effective research could not begin until the following morning. ${ }^{33}$ The special collections department of the University of Southern California library similarly requires a researcher to re-

${ }^{33}$ Interview with James Mink, historical manuscript librarian, January 18, 1966. quest records a day before he needs them. Such requirements can make it difficult to coordinate a research schedule. ${ }^{34}$

Graduate students frequently comment that the hours maintained by special collections make it difficult for them to use the collections. Ordinarily, the hours are from nine to five, with an hour out for lunch. Those who seem to be most inconvenienced are working students or students at one institution who want to use the special collection at another. Both professors and students have expressed wishes that their libraries would keep longer hours at night, as well as stay open more on weekends and holidays. Libraries that close during weekends and vacations seem to be geared to undergraduates rather than graduate students and professors who often can work in the library most effectively during these periods. One problem connected with using most research libraries late at night is that trained librarians are often not available and student assistants are unable to give proper service.

The attitudes of librarians toward both ordering microforms and providing decent reading facilities for them greatly influence relations with historians. Some major research libraries have been reluctant to purchase microforms, despite faculty pressure to do so. On occasion this reluctance appears to have stemmed from a librarian's notion that research with microforms was undignified. These librarians have preferred to buy manuscripts. Although one university librarian accedes to historians' wishes to acquire microforms, he "is reluctant to make the necessary arrangements for their easy use." In the university's main library, there are only two microfilm readers for general purposes. Because of widespread dissatisfaction with this university library, in March 1966, graduate students

\footnotetext{
${ }^{34}$ Interview with Thomas F. Andrews, graduate student, January 20, 1966.
} 
and faculty members circulated a petition calling for improvements. One historian termed the library service "miserable in almost all respects."

Putting an even greater strain on relations between libraries and departments of history is a lack of standard secondary works. This is particularly the case in universities which have recently inaugurated doctoral programs in history. A student at such a university described its library facilities as "particularly limited, except for magazines. . . . The ... library is wanting in basic books." Moreover, those books listed in the card catalog are hard to locate because of misshelving, and it sometimes takes more than a month for books to be returned to the shelves after they have been checked in. One of the problems with this library, according to a professor, is that it is "grossly overused by undergraduates and underused by graduate students." To get at the library's holdings, graduate students "must elbow their way in through hordes of undergraduates." A doctoral candidate at another university complained similarly that the great influx of undergraduates has made the library's service to graduate students inadequate. One consequence of this lack of basic books at universities in the Washington, D.C., area is that graduate students depend almost entirely on the Library of Congress, a condition David S. Sparks describes as the "Library of Congress syndrome." "Students feel that they must go there to be respectable, even if it's to have lunch, read the newspaper, or chat with friends. There is a great deal of work that scholars could do at their own libraries, rather than going to the LC. It's just that they feel it's somehow more scholarly to read the same work in the LC than at another library." 35

Both the University of Massachusetts 1966. and the City University of New York have recently begun doctoral programs in history without having developed research collections. Their doctoral candidates must therefore depend on other libraries for books. Those at CUNY must rely on books from the libraries of the component colleges-Brooklyn, Queens, City College of New York, and Hunteror using the New York public library. The attendant difficulties force students "to scrounge to get books for graduate research at CUNY."36 The institution made some effort to alleviate this problem, however, by locating its graduate center directly across 42nd Street from the New York public library! At the University of Massachusetts, the library's "fair working relations with the department of history" result partly from the fact "that we never have what they want. . . In the department of history as a whole, professors of non-U.S. history seem more aggressive in building the library collections than those in U.S. history." "37 It should be noted that some of the pressure is removed from the University of Massachusetts Library by its consortium arrangement with Amherst, Smith, and Mt. Holyoke Colleges.

Even when a university has had a successful doctoral program for some years and its library has systematically tried to build research collections, professors sometimes think of the library in terms of its holdings before graduate work began. At one rapidly growing institution, the library generally has excellent relations with historians, but protests that the university is "plagued with an inferiority complex." Too many faculty members often assume that the library's holdings are commensurate with its sometime "cow-college" status.

At other university libraries various

\footnotetext{
${ }^{36}$ Interview with Selma C. Berrol, graduate student, July $21,1966$.

${ }^{37}$ Interview with Benton L. Hatch, associate librarian for special collections, July 15, 1966.
} 
problems and lapses in service keep relations between historians and librarians somewhat strained. Professors at one university are outspoken about the shortcomings of their library and contend that the librarian is uninterested in research and provides inadequate facilities for it. There are also indications that the university administration is not supporting the library properly and that the situation might be improved, given this support. Lack of coordination between one library staff and the department of history resulted in "a great battle" over newspapers. The librarian sent all the state newspapers to the state historical society without consulting the department. "So with one fell swoop one of our major research resources was removed from us." If the department wants any of this material in the future, it must buy microfilmed copies. Historians have expressed dissatisfaction with university libraries that are uninterested in developing manuscript collections. A few years ago one university not only refused to acquire manuscripts, but actually transferred important collections to the efficient state library in the same city. Subsequently, the university has resumed collecting. A constant frustration to historians and librarians at many universities is the great loss from pilferage and mutilation of library materials. Many of the foregoing problems can be understood in light of the department's experience at the University of Virginia. Up to 1961, the graduate history enrollment was fifty students, but by 1965 there were one hundred and fifty. ${ }^{38} \mathrm{Sim}$ ilar conditions elsewhere explain some of the difficulties researchers have with university libraries whose facilities have not expanded commensurately with enrollments.

While scholars experience annoyance with conditions that hamper research at

\footnotetext{
${ }^{38}$ Interview with Edward Younger, November 16,
} 1965. their own universities, difficulties encountered while traveling become magnified. This is especially so if the researcher did not want to travel from the outset. Some graduate students, according to their professors, are reluctant to travel. Howard S. Miller says that many doctoral candidates at the University of Southern California are natives of the region and do not want to leave. ${ }^{39}$ Perhaps they assume, as do some students at Columbia University, that if the records are not in their area, they are not to be found anywhere. ${ }^{40}$ The reason his graduate students at the University of Oklahoma were reluctant to travel, thought Arthur H. DeRosier, Jr., was that they wanted to work quickly "and in a cloistered area."41 Professors at the Universities of Texas, Kansas, and Minnesota report that students either cannot afford travel or are unwilling to spend their own money on it. ${ }^{42}$ If students with these attitudes are required to travel, they probably begin their research expecting the worst. When they do have problems at other university libraries, it may be that the curators feel that their first obligation is to give service to resident scholars and that visitors should be satisfied with whatever they get.

Evidence from both academic and non-academic repositories indicates that approximately half their researchers come from outside the locality. ${ }^{43}$ Whitfield J. Bell, Jr., librarian of the American Philosophical Society, says that the

\footnotetext{
39 Interview, January 20, 1966.

40 Interview with James P. Shenton, July 19, 1966. Mr. Shenton said Columbia students include New England in their region.

41 Interview, March 7, 1966.

42 Interviews with Barnes F. Lathrop, March 10, 1966; Clark S. Griffin, April 22, 1966; Robert F. Berkhofer, Jr., May 20, 1966.

${ }^{43}$ Interviews with Harriett C. Owsley, archivist, Tennessee State Library and Archives, December 15, 1965; Colton Storm, head of special collections, Newberry library, August 23, 1966; E. L. Inabinett, director, South Caroliniana library, December 6, 1965; Herman H. Fussler, director, University of Chicago library, August 23, 1966; Howard H. Peckham, director, W. L. Clements library, August 17, 1966.
} 
APS gets fewer graduate students from the University of Pennsylvania than elsewhere, and of those who do come, more are in the American civilization program than in American history. ${ }^{44}$ With the fact of traveling researchers well established, custodians of original sources-particularly at universities-should recognize the fact that while they are serving the sojourner, some distant custodian is likely dealing with a researcher from their own institution. The ethical implications should not go unrecognized.

Among the most common complaints of traveling scholars is the difficulty of gaining admission to certain private libraries. While some of these non-academic institutions receive young postdoctoral researchers with coolness, their response to graduate students can be glacial. Often the difficulty lies in getting beyond cloakroom attendants and the clerical staff. Once these defenses are breached and the researcher proves his serious interest, the libraries can be most helpful and hospitable. In some instances, however, scholars have written to obtain permission to see certain collections in advance of a visit only to find upon arrival that curators are still reluctant to grant access to the materials. Such cases naturally make researchers wonder whose interests curators are trying to serve.

Scholars frequently encounter difficulties when doing research in church libraries and archives, especially if the church has been involved in controversial issues. So long as the material desired does not touch on matters related to church practices or doctrine, researchers experience little trouble. But when sensitive issues are involved, scholars may either be denied access to records or have to submit their notes for clearance. However much scholars may chafe at such restrictions, they must recognize the essentially private nature of church records and be grateful for the opportunity to use them. For their part, churches should realize that they can make great contributions to scholarship by granting liberal access to their records.

Public research institutions, such as the Library of Congress and the New York public library, make great efforts to satisfy the needs of their researchers. But with their tremendous number of resources and users, service can often be uneven. Usually it is not the experienced researcher who gets inadequate treatment, but the person paying his first visit to the institution-the person who has not yet learned whom to call on for advice and assistance. Many researchers report that their difficulties at these libraries stem from their contacts with clerks at the front desk, who are likely to give ill-considered and casual advice that results in researchers making false starts. Despite any shortcomings in service in the Library of Congress' manuscript division, David C. Mearns says the division's relations with historians are "one of our great joys." 45 Mearns was chief of the division until his retirement in December 1967, having been on the Library of Congress staff for forty-nine years. During his last years in the manuscript division, he inaugurated a seminar to acquaint university students with the conditions encountered in manuscript research.

Graduate students from across the country do research at the New York public library, but those from New York City naturally use it most. Both students and library staff agree that they have mutual problems. A doctoral candidate from Columbia University says using the NYPL is a bit harrying. His major complaint is that the American history room closes at six o'clock so that it is impossible to work there at night. While some graduate students at the 
City University of New York feel they have poor relations with the NYPL, another says that regardless of any difficulties, the NYPL is a marvelous resource. She admits that it is physically uncomfortable and that researchers have to contend with drunks who come in to get out of the cold. Harold D. McDonald, chief of the American history division of the NYPL, considers the library's relations with historians "rather negative, particularly with professors. They do not make suggestions on acquisitions, never let us see the reading lists they give their students, never ask how certain problems should be handled."46

Historians have commented on several other conditions that have produced unpleasant relations with repositories. These include having to pay fees to use manuscripts and having to spend unwarranted amounts of time getting permission to use certain records. They have condemned one institution's practice of parceling out only five pieces of material at a time. This involves researchers in filling out numerous forms requesting more manuscripts and then waiting for their delivery. Curators who give slow service because of unfamiliarity with their materials have annoyed researchers. One graduate student was disgusted with ex post facto restrictions a military librarian tried to impose. The librarian told the researcher that he should not have been allowed to see some of the 1919 Graham Committee hearings on the conduct of World War I and asked him not to use his notes.

Working relationships between departments of history and historical societies are often symbolized by their close physical proximity, as in Madison (Wisconsin) and Lincoln (Nebraska). But in some instances tension exists between researchers and the societies, with resultant loss to each. A common cause

\$6 Interview, July 22, 1966. for such tension is when the societies are staffed by political appointees or amateurs incapable of rendering professional service. Academic historians often have little patience with amateurismeither in the administration or programs of historical societies-and are quick to show it. Unfortunately this attitude, while legitimate regarding amateur scholarship, can impede the work of serious researchers by causing a historical society to react defensively by restricting access to manuscripts. Another reason for strains between universities and historical societies is competition in manuscript collecting. When there is such rivalry, departments of history usually support the university. This condition may result in graduate students experiencing difficulties in using the research facilities of the historical society. Significantly, professors in universities which have prickly relations with their historical societies report that their state archives receive graduate students cordially.

The need is great for closer communication between academic historians and those in museums, archives, and historical societies. The American Association for State and Local History makes an excellent effort to provide the needed meeting ground, but too few academicians know of its work or are interested in it. Some look upon the AASLH with disdain. ${ }^{47}$ Nonetheless, historians can only profit by establishing amicable relations with custodians of original sources necessary for their research.

Historians should take satisfaction in the rapport they have established through the years with custodians of original sources. One of the reasons for these good relations is that a significant number of custodians are themselves historians and understand researchers' needs. Many of the difficulties historians experience in their research arise from

\footnotetext{
${ }^{47}$ Cf., Walter Muir Whitehill, Independent Historical Societies (Boston: The Athenaeum, 1962).
} 
the repositories' inadequate physical facilities and inadequate staffs-conditions susceptible to improvement, given requisite funds. It would behoove historians, therefore, to lend their support to efforts to meet the material needs of libraries, historical societies, and archives. The needs are particularly great with private agencies, for, by making their resources available for doctoral research, they are supporting the work of the universities, but without financial aid from them. These older independent historical societies and libraries developed in the age of the amateur, for until the last quarter of the nineteenth century there were no professional historians in them, and their support was derived from collectors, antiquarians, and genealogists. Hence their problems in our own time: designed to serve a local constituency with modest demands, they are now overrun by platoons of graduate students and get more mail requests for Xerox copies of their records than they can possibly fill. They have no alumni, and the United States Office of Education has never heard of them. How do they meet these new demands? Gladly, and without asking for cash compensation, but their underpaid and often superannuated staffs creak at the joints and are sometimes a bit crotchety in their manners-and no wonder!

Researchers can express appreciation to these repositories in several ways. They can mind their own manners and show respect for the unique materials placed in their hands. They might thank the librarian or director when they have been served well, or write him a letter. If the membership of the organization is open, they can join and subscribe to its journal, thus manifesting their appreciation concretely. These things graduate students in our affluent age of fellowships and travel grants too seldom do. State and federal research agencies share this need for historians' support. Although they receive public monies, they often are inadequately funded. Historians should ascertain that appropriations for public historical societies, libraries, and archives are adequate and they should be willing to lobby with legislatures when they are not.

While relationships between custodians and researchers are predominantly satisfactory, both parties can take steps to improve them. Historians and librarians on university campuses can recognize each other's needs and work to meet them. And both historians and custodians involved in extramural research should realize that problems always seem heightened to travelers. Nonetheless, the problems are real, and custodians should operate on the premise that their basic function is to serve scholarship, not impede it. 